Krishna, K.S., Bull, J.M. and Scrutton, R.A. (2001). Evidence for multiphase folding of the central Indian Ocean lithosphere. Geology, 29, (8), 715-718. (doi:10.1130/0091-7613(2001)029<0715:EFMFOT>2.0.CO;2).

\title{
Evidence for multiphase folding of the central Indian
}

\section{Ocean lithosphere}

\author{
K.S. Krishna National Institute of Oceanography, Dona Paula, Goa - 403004, India \\ J.M. Bull School of Ocean and Earth Science, Southampton Oceanography Centre, Southampton University, \\ SO14 3ZH, UK
}

R.A. Scrutton Department of Geology and Geophysics, Edinburgh University, Edinburgh, EH9 3JW, UK

\begin{abstract}
Long-wavelength (100-300 km) folding in the central Indian Ocean associated with the diffuse plate boundary separating the Indian, Australian, and Capricorn plates is Earth's most convincing example of organized large-scale lithospheric deformation. To test the timing and mechanics of this deformation as implied by plate-kinematic and deformation models, we present a new analysis of the seismic stratigraphy of the Bengal Fan sediments. This shows that the folding of the oceanic lithosphere was multiphase, with major events in the Miocene (8.0-7.5 Ma), Pliocene (5.0-4.0 Ma) and Pleistocene (0.8 Ma). The Miocene phase was the most intense and involved deformation of an area south of $1^{\circ} \mathrm{S}$, whereas in the Pliocene the activity shifted northward. In the final phase (Pleistocene) the activity was focused in the equatorial region. No evidence was found
\end{abstract}


for deformation prior to 8.0-7.5 Ma. The spatial extent of the Pleistocene folding event overlaps the Pliocene and/or Miocene folding events and coincides with both the area of most active faulting and the zone of greatest historical seismicity. The seismic data show that the timing of reverse faulting, and thus more significant shortening of the lithosphere, generally coincided with the phases of folding, but there are examples of folding of the oceanic lithosphere without associated reverse faulting.

Keywords: Indian Ocean, Intraplate Tectonics, Bengal Fan, Folding, Unconformities INTRODUCTION

The oceanic lithosphere in the central Indian Ocean has been deformed systematically by the concentration of compressional stresses related to the plate-boundary configuration and the ongoing collision of India with Asia. The deformation has occurred on two major spatial scales: (1) long-wavelength (100-300 km) folding of the oceanic lithosphere and overlying sediments, and (2) reverse faulting of 5-20-km-wide blocks (Weissel et al., 1980; Neprochnov et al., 1988; Bull, 1990; Bull and Scrutton, 1990, 1992; Chamot-Rooke et al., 1993; Krishna et al., 1998). A major structural unconformity resulting from the deformation process was dated by the Ocean Drilling Program (ODP Leg 116 sites), indicating that significant deformation of the central Indian Ocean lithosphere began at ca. 8.0-7.5 Ma (Leg 116 Shipboard Scientific Party, 1987; Curray and Munasinghe, 1989; Cochran, 1990). The location of this deformation has been placed in a plate kinematic setting (Royer and Gordon, 1997; Gordon et al., 1998) by splitting the traditionally defined Indo-Australian plate into the Indian, Australian, and Capricorn plates with multiple, diffuse, plate boundaries. At present, there is some difficulty in reconciling the plate kinematic analysis (Gordon et al., 1998) with the observed seismic stratigraphy and available deep-sea drilling. 
In this paper we address in detail the nature of deformation in the central Indian Ocean - whether it was sudden, continuous, or multiphase - and consider its timing. In addition we look at evidence for interaction of the long-wavelength folding and the reverse faults: which was initiated first and does one drive the other, and what are the implications for tectonic models of the deformation? The spatial occurrence of the unconformities allowed us to understand the deformation process in space and time. Analysis of fault throws at three regional unconformities and a sediment reflector immediately above basement allows the determination of how the long-wavelength folding and reverse faulting have interacted.

\section{SEISMIC STRATIGRAPHY OF THE BENGAL FAN SEDIMENTS}

An analysis of seismic stratigraphy was completed along three regional N-S $\left(81.5^{\circ} \mathrm{E}\right.$, $83.7^{\circ} \mathrm{E}$, and $87^{\circ} \mathrm{E}$ ) profiles (Fig. 1). Further seismic reflection profiles described by Bull and Scrutton (1992) and Krishna et al. (1998) were also used in this study. The lithosphere in the central Indian Ocean is systematically folded as crests and troughs (Fig. 2). Within our data set we identify 12 long-wavelength fold structures ranging from 75 to $300 \mathrm{~km}$ in wavelength and 1 to $2 \mathrm{~km}$ in relief. Over 500 high-angle reverse faults and small-scale folds are observed within the deformation zone. At some locations, for example, near the ODP Leg 116 sites (Leg 116 Shipboard Scientific Party, 1987; Cochran, 1990; Bull and Scrutton, 1992) and in the vicinity of $3.5^{\circ} \mathrm{S}$ east of the $86^{\circ} \mathrm{E}$ Fracture Zone (Krishna et al., 1998), faulting has significantly modified the regular long-wavelength basement topography (Fig. 2) to produce a "sharp-crest - broad-trough" profile. 
Four seismic sequences are identified in the sediment column and are separated by three regional structural unconformities (Fig. 2). They are correlated to bio- and lithostratigraphic results of ODP Leg 116 sites (Stow et al., 1990; Cochran, 1990) to define their ages. The oldest and youngest unconformities have ages of late Miocene (8.0-7.5 Ma) and late Pleistocene (0.8 Ma) and correspond to unconformities " $\mathrm{A}$ ” and "B" respectively of Cochran (1990). The middle one appears to be earliest Pliocene in age (5.0-4.0 Ma), approximately correlated to the boundary between depositional units IVA and IVB (Stow et al., 1990). The regional extent of at least one of the unconformities (Pliocene) may be confirmed at DSDP (Deep Sea Drilling Project) Site 218 (Fig. 1), where a pulse of turbidite sediment deposited in early Pliocene time has an unconformity immediately beneath it dated as latest Miocene (5.0-6.0 Ma), the "upper unconformity” of Curray and Moore (1971) and Moore et al. (1974). This event was interpreted as marking the onset of deformation in the vicinity of DSDP Site 218. Now that we can recognize three regional unconformities and observe their stratigraphic relationships, it seems likely to us that the event at DSDP Site 218 is the lateral equivalent of the earliest Pliocene unconformity at the ODP Leg 116 sites and does indeed mark the onset of deformation at Site 218.

The Miocene unconformity, well developed in a large region between $1^{\circ} \mathrm{S}$ and $7^{\circ} \mathrm{S}$ in the central Indian Ocean, is uniformly folded (Figs. 2 and 3) and indicates the occurrence of the first phase of long-wavelength lithospheric deformation. The Miocene deformation occupies an area of $\sim 0.7 \times 10^{6} \mathrm{~km}^{2}$ (Fig. 4). The Pliocene unconformity is particularly well recognized as long-wavelength fold structures north of the ODP Leg 116 sites (Figs. 2 and 3). East of $84^{\circ} \mathrm{E}$, the Pliocene unconformity has a somewhat smaller magnitude and is developed between $1.5^{\circ} \mathrm{S}$ and $7^{\circ} \mathrm{N}$. This unconformity represents the second major phase of longwavelength fold formation at 5.0-4.0 Ma and also has an areal coverage of $\sim 0.7 \times 10^{6} \mathrm{~km}^{2}$. It 
occurs north of the Miocene area, but with some overlap (Fig. 4). The Pleistocene unconformity is developed near the equator in regions where the lithosphere had been previously folded in either Miocene or Pliocene time and in a small zone of both Miocene and Pliocene folding (Figs. 2 and 4). The Pleistocene deformation is relatively mild. It is observed that, since the Pliocene folding, deformation has been more continuous in the northeast quadrant, whereas in other areas, the deformation has been episodic, with a discrete folding event at 0.8 Ma.

In view of the evidence from Gordon et al. (1998) for earlier shortening, a thorough examination was made of the pre-Miocene stratigraphy for earlier long-wavelength folding, but no onlap patterns suggestive of deformation were found. Our results indicate that the deformation started at 8.0-7.5 Ma and not earlier. It is possible that weak folding below seismic resolution occurred before 8.0-7.5 Ma, but we think this is unlikely given that ongoing and/or low-amplitude folding between 8.0 Ma and the present is well recorded by the seismic stratigraphy.

\section{RELATIONSHIPS BETWEEN UNCONFORMITIES AND BENGAL FAN TURBIDITES}

The sediments in the deformation zone reach a total thickness of 2.4s two-way time (TWT) in the vicinity of $6^{\circ} \mathrm{N}$ on profile $\mathrm{C}$ (Fig. 2). From there, their thickness decreases uniformly to $7^{\circ} 40^{\prime} S$ where they abut exposed basement topography. The bulk of this decrease arises from the pre-deformation Bengal Fan. Prior to deformation the Fan formed a thick layer of sediments dating from about $40 \mathrm{Ma}$, which decreased in thickness away from its source (Ganges-Brahmaputra-Tsangpo River system). Isopachs of syndeformation sediments show highly variable thickness however, both locally, over fault blocks, and 
regionally. For example, syndeformation sediment is thinner over long-wavelength fold crests and in places is absent (panel 3, Fig. 3). The thickness of sediment deposited from 8.0 to 4.0 Ma and from 4.0 to $0.8 \mathrm{Ma}$ is highly variable from one trough to another, particularly in the vicinity of ODP Leg 116 drill sites (Fig. 2). Such variability suggests the frequent migration of the main turbidite channel in response to deformation-related topography. Following a phase of folding we would expect this topography to be buried eventually.

If the seismic sequences and their boundaries (structural unconformities) are correlated to lithostratigraphic units at ODP Leg 116 sites (Stow et al., 1990; Cochran, 1990), the top two boundaries (lower Pliocene and upper Pleistocene) are associated with changes in sediment character (base of lithological units II and IVA), with the introduction of coarser, silty turbidites. However, the earliest unconformity (upper Miocene) does not correspond to any change. Nevertheless, it is reasonable to think in terms of a link between a phase of deformation, uplift in the sediment source area and sediment supply.

\section{INTERACTION OF LONG-WAVELENGTH FOLDING AND REVERSE}

\section{FAULTING}

The reverse faulting generates $\sim 90 \%$ of the shortening between the Indian and Australian plates in the central Indian Ocean. It generally modifies the long-wavelength folding to produce a "sharp-crest-broad-trough morphology" (Fig. 2; Bull, 1990). We measured the vertical throws in terms of two-way traveltimes on all the reverse faults present on three regional profiles and show them above the line drawings of seismic data (Fig. 2). The throws are measured at a sedimentary reflector immediately above basement in a manner identical to that of Van Orman et al. (1995). A negative throw represents a fault that dips to 
the south; a positive throw represents a fault that dips to the north. The faults are distributed throughout most of the deformation zone and have produced varied offsets in oceanic basement, but there is no correlation between the direction and magnitude of the fault throws and their position with respect to the long-wavelength folds. For example, some fold crests are associated with no faults at all (panel 1, Fig. 3); others, with only small fault throws (first fold crest on profile B, Fig. 2). Elsewhere, an increase in fault throw is seen within a fold trough (profile B, Fig. 2).

With some notable exceptions, fault continuity is generally observed up to the level of the most recent long-wavelength, fold-related unconformity in any particular region. In the Miocene-only fold region, the faults do not continue above the Miocene unconformity (panel 3, Fig. 3), whereas in the Pleistocene fold area, the faults continue up to the level of the Pleistocene unconformity (panel 4, Fig. 3). The fact that the Pleistocene folded region (near the equator) is spatially associated with the highest density of historical seismicity (Buchanan, 1998) points to this also being the area of current fault activity. In the vicinity of the equator at $81.5^{\circ} \mathrm{E}$ (north of ODP Leg 116 sites), there is evidence that folding (Pliocene age) can occur without associated faulting (panel 1, Fig. 3). The observation that folding can take place without reverse faulting is at variance with numerical models of the deformation that utilise weaknesses within the crust as a prerequisite for folding (Wallace and Melosh, 1994; Gerbault, 1999).

\section{SUMMARY AND CONCLUSIONS}

Analysis of the seismic stratigraphy has shown that major long-wavelength folding occurred at 8.0-7.5, 5.0-4.0 and 0.8 Ma in overlapping regions (Fig. 4) within the central 
Indian Ocean. Deformation and shortening has occurred since $8.0 \mathrm{Ma}$, but the style of deformation has varied across the deformation zone. In the northeastern part (east of $84^{\circ} \mathrm{E}$ and north of the equator), the deformation appears to have been quasi-continuous since the Pliocene. In the rest of the area, the deformation has been more episodic; major events have occurred in Miocene, Pliocene, and Pleistocene times, and some smaller events occurred in between. Regional deformational events at 5.0-4.0 and 0.8 Ma in the central Indian Ocean were coincident with the early Pliocene and late Pleistocene Bengal Fan turbidite pulses, which allows us to understand the changes in deposition of fan sediments. With the observation that faulting terminates below the major fold-related unconformities, we can infer that the locus of shortening has migrated with the folding. Further work is needed to test whether the folding events are simply linked to plate kinematics, or whether the similar period (3.0-4.0 m.y.) between major folding episodes is linked to fundamental lithospheric rheologic properties.

\section{ACKNOWLEDGEMENTS}

Krishna was supported by a Royal Society/Indian National Science Academy fellowship at Southampton Oceanography Centre. National Institute of Oceanography contribution number 3637. 


\section{REFERENCES CITED}

Buchanan, S., 1998, Seismicity and tectonics of the central Indian Ocean Basin [Ph.D. thesis]: Edinburgh, University of Edinburgh, 220p.

Bull, J.M., 1990, Structural style of intraplate deformation, central Indian Ocean Basin: Evidence for the role of fracture zones: Tectonophysics, v. 184, p. 213-228.

Bull., J.M., and Scrutton, R.A., 1990, Fault reactivation in the central Indian Ocean and the rheology of oceanic lithosphere: Nature, v. 344, p. 855-858.

Bull, J.M., and Scrutton, R.A., 1992, Seismic reflection images of intraplate deformation , central Indian Ocean, and their tectonic significance: Geological Society [London] Journal, v. 149, p. 955-966.

Chamot-Rooke, N., Jestin, F., de Voogd, B., and Phedre Working Group, 1993, Intraplate shortening in the central Indian Ocean determined from a 2100-km-long north-south deep seismic reflection profile: Geology, v. 21, p. 1043-1046.

Cochran, J.R., 1990, Himalayan uplift, sea level, and the record of Bengal Fan sedimentation at the ODP Leg 116 sites, in Cochran, J.R., Stow, D.A.V. et al., Proceedings of Ocean 
Drilling Program, Scientific results Volume, 116: College Station, Texas, Ocean Drilling Program, p. 397-414.

Curray, J.R., and Moore, D.G., 1971, Growth of the Bengal deep-sea fan and denudation in the Himalayas: Geological Society of America Bulletin, v. 82, p. 563-572.

Curray, J.R., and Munasinghe, T., 1989, Timing of intraplate deformation, northeastern Indian Ocean: Earth and Planetary Science Letters, v. 94, p. 71-77.

Gerbault, M., 1999, Do faults trigger folding in the lithosphere?: Geophysical Research Letters, v. 26, p. 271-274.

Gordon, R.G., DeMets, C., and Royer, J-Y., 1998, Evidence for long-term diffuse deformation of the lithosphere of the equatorial Indian Ocean: Nature, v. 395, p. 370374.

Krishna, K.S., Ramana, M.V., Gopala Rao, D., Murthy, K.S.R., Malleswara Rao, M.M., Subrahmanyam, V., and Sarma, K.V.L.N.S., 1998, Periodic deformation of oceanic crust in the central Indian Ocean: Journal of Geophysical Research, v. 103, p. 17859-17875.

Leg 116 Shipboard Scientific Party, 1987, Collisions in the Indian Ocean: Nature, v. 330, p. $519-521$.

Moore, D.G., Curray, J.R., Raitt, R.W., and Emmel, F.J., 1974, Stratigraphic-seismic section correlations and implications to Bengal Fan history, in von der Borch, C. C., Sclater, 
J.G., et al., Initial Reports of the Deep Sea Drilling Program, 22: Washington (U.S. Govt. Printing Office), p. 403-412.

Neprochnov, Yu. P., Levchenko, O.V., Merklin, L.V., and Sedov, V.V., 1988, The structure and tectonics of the intraplate deformation area in the Indian Ocean: Tectonophysics, v. 156, p. 89-106.

Royer, J-Y., and Gordon, R.G., 1997, The motion and boundary between the Capricorn and Australian plates: Science, v. 277, p. 1268-1274.

Sandwell, D.T., and Smith, W.H.F., 1997, Marine gravity from Geosat and ERS-1 satellite altimetry: Journal of Geophysical Research, v. 102, p. 10039-10054.

Stow, D.A.V., Amano, K., Balson, P.S., Corrigan, J., Raman, C.V., Tiercelin, J-J., Townsend, M., and Wijayananda, 1990, Sediment facies and processes on the distal Bengal Fan, Leg 116, in Cochran, J.R., Stow, D.A.V., et al., Proceedings of Ocean Drilling Program, Scientific results Volume, 116: College Station, Texas, Ocean Drilling Program, p. 377396.

Van Orman, J., Cochran, J.R., Weissel, J.K., and Jestin, F., 1995, Distribution of shortening between the Indian and Australian plates in the central Indian Ocean: Earth and Planetary Science Letters, v. 133, p. 35-46.

von der Borch, C.C., Sclater, J.G., Gartner, S., Hekinian, R., Johnson, D.A., Mcgowran, B., Pimm, A.C., Thompson, R.W., Veevers, J.J., and Waterman, L.S., 1974, Site 218, in von 
der Borch, C.C., Sclater, J.G., et al., Initial Reports of the Deep Sea Drilling Program, 22: Washington (U.S. Govt. Printing Office), p. 325-348.

Wallace, M.H., and Melosh, H.J., 1994, Buckling of a pervasively faulted lithosphere: Pure and Applied Geophysics, v. 142, p. 239-261.

Weissel, J.K., Anderson, R.N., and Geller, C.A., 1980, Deformation of the Indo-Australian plate: Nature, v. 287, p. 284-291.

\section{Figure captions:}

Figure 1. Locations of the three long seismic reflection profiles in central Indian Ocean superimposed on satellite gravity field (Sandwell and Smith, 1997). Seismic stratigraphic interpretation of profiles A, B, and C are shown as line drawings in Figure 2. Locations of DSDP Sites 215 and 218 and ODP Leg 116 sites are shown by circles.

Figure 2. Line drawings of interpreted seismic data along profiles $\mathrm{A}\left(81.5^{\circ} \mathrm{E}\right), \mathrm{B}\left(83.7^{\circ} \mathrm{E}\right)$ and $\mathrm{C}\left(87.0^{\circ} \mathrm{E}\right)$. Panels outlined and numbered 1, 2, 3, and 4 are in Figure 3 and show how unconformities have recorded formation of long-wavelength folding at different times. Panel 1 shows clear Pliocene and Pleistocene folding; panel 2 shows Miocene and Pliocene folding; panel 3 shows only Miocene folding; panel 4 shows Miocene and Pleistocene folding. Some steep isolated basement rises north of $200 \mathrm{~km}$ along profile A act as a barrier limiting western extent of Bengal Fan sediments. Southern extent of Bengal Fan sediments is seen on both profiles B and C at about the same latitude, $7^{\circ} 40^{\prime} \mathrm{S}$. Major basement undulation covered with 
thin upper Miocene sediments is observed along profile B. This was initially part of basement structure of Afanasy Nikitin Seamount, but during late Miocene time, it was uplifted to form part of a long-wavelength fold structure. Positions of reverse faults and their vertical throws are shown above each profile. Free-air gravity anomalies (FAA) for each profile shows presence of 100-300-km-wavelength folding.

Figure 3. Seismic reflection profile panels showing how long-wavelength folding occurred in different phases in different areas within deformation zone. On all panels the three unconformities (Miocene, Pliocene, and Pleistocene) are visible, but not all contribute to folding in each area. Panel 1 shows part of line A along $81.5^{\circ} \mathrm{E}$ near the equator, where Miocene "unconformity” is conformable. Sediments clearly document a major Pliocene longwavelength folding episode and a milder Pleistocene folding event. No faults are cutting Pliocene folding. Panel 2 shows part of line A along $81.5^{\circ} \mathrm{E}$ centered at $2^{\circ} \mathrm{S}$ and reveals Miocene and Pliocene folding. Faults continue up to the Pliocene folding. Panel 3 shows part of line A along $81.5^{\circ} \mathrm{E}$ centered at $4.5^{\circ} \mathrm{S}$; only Miocene folding is present, and the Pliocene and Pleistocene unconformities onlapping against the Miocene strata. Faults are seen to terminate at Miocene strata and have not propagated into overlying sediments. Panel $\mathbf{4}$ shows part of line $\mathrm{B}$ along $83.7^{\circ} \mathrm{E}$ centered at $1.5^{\circ} \mathrm{S}$ where the Pliocene "unconformity" is conformable. Sediments clearly record major folding episodes and fault continuity at Miocene and Pleistocene time.

Figure 4. Deformation of oceanic lithosphere in space and time in central Indian Ocean. Gray shading shows position of diffuse plate boundary separating the Capricorn, Indian, and Australian plates (Royer and Gordon, 1997). Superimposed on this area are the approximate spatial extents of long-wavelength folding at three different times (8.0-7.5, 5.0-4.0, 0.8 Ma). 
Note that earliest folding event is concentrated in south, whereas the Pliocene event (5.0-4.0 Ma) extends farther northward. Spatial distribution of Pleistocene folding event overlaps Pliocene and/or Miocene folding event zones and coincides with area of most active faulting and zone of greatest historical seismicity. Positions of seismic reflection profiles are shown: solid lines from Bull and Scrutton (1992); dotted lines from Krishna et al. (1998). NER, CLR and ST are Ninetyeast Ridge, Chagos-Laccadive Ridge system, and Sumatran Trench, respectively. 


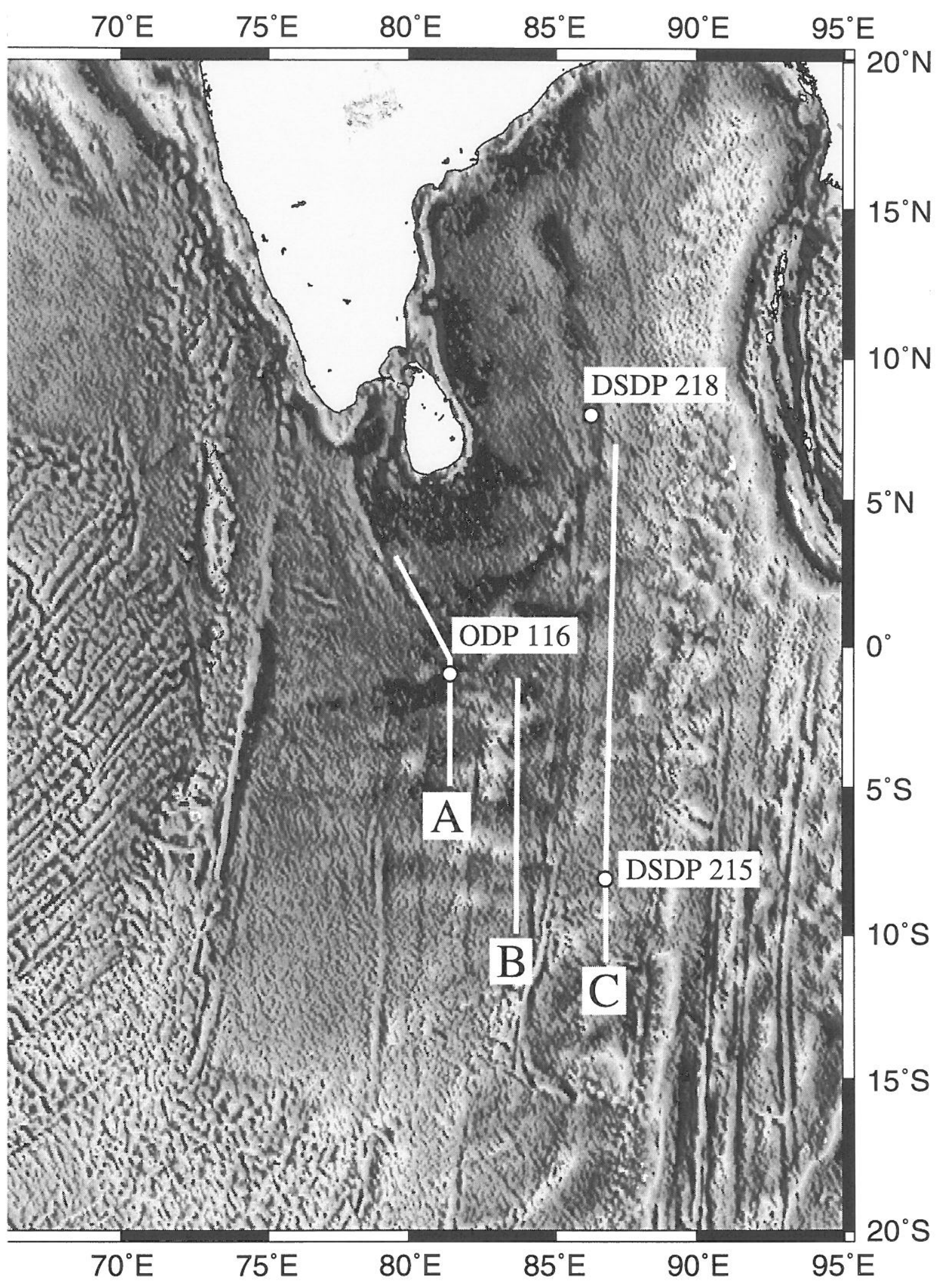




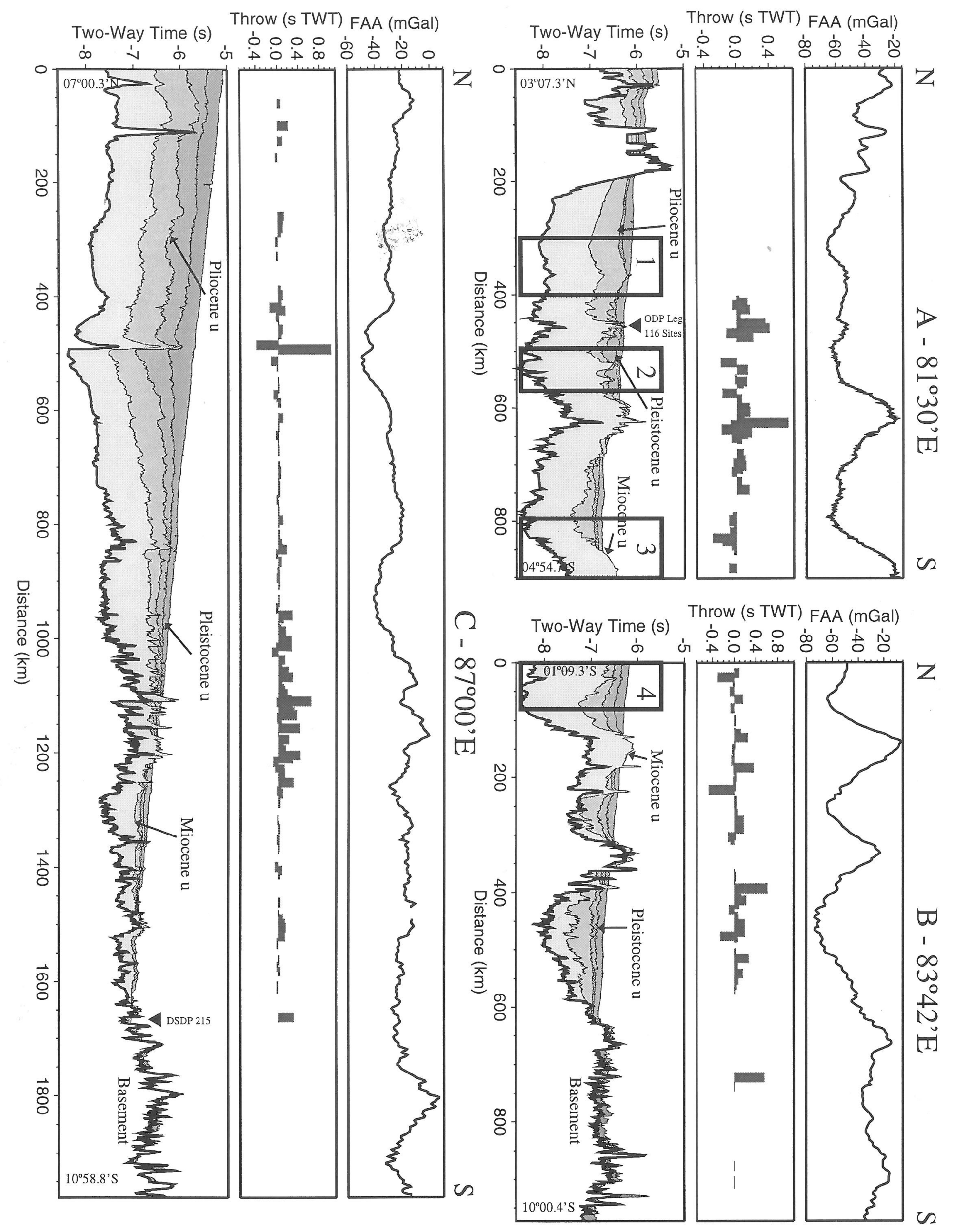



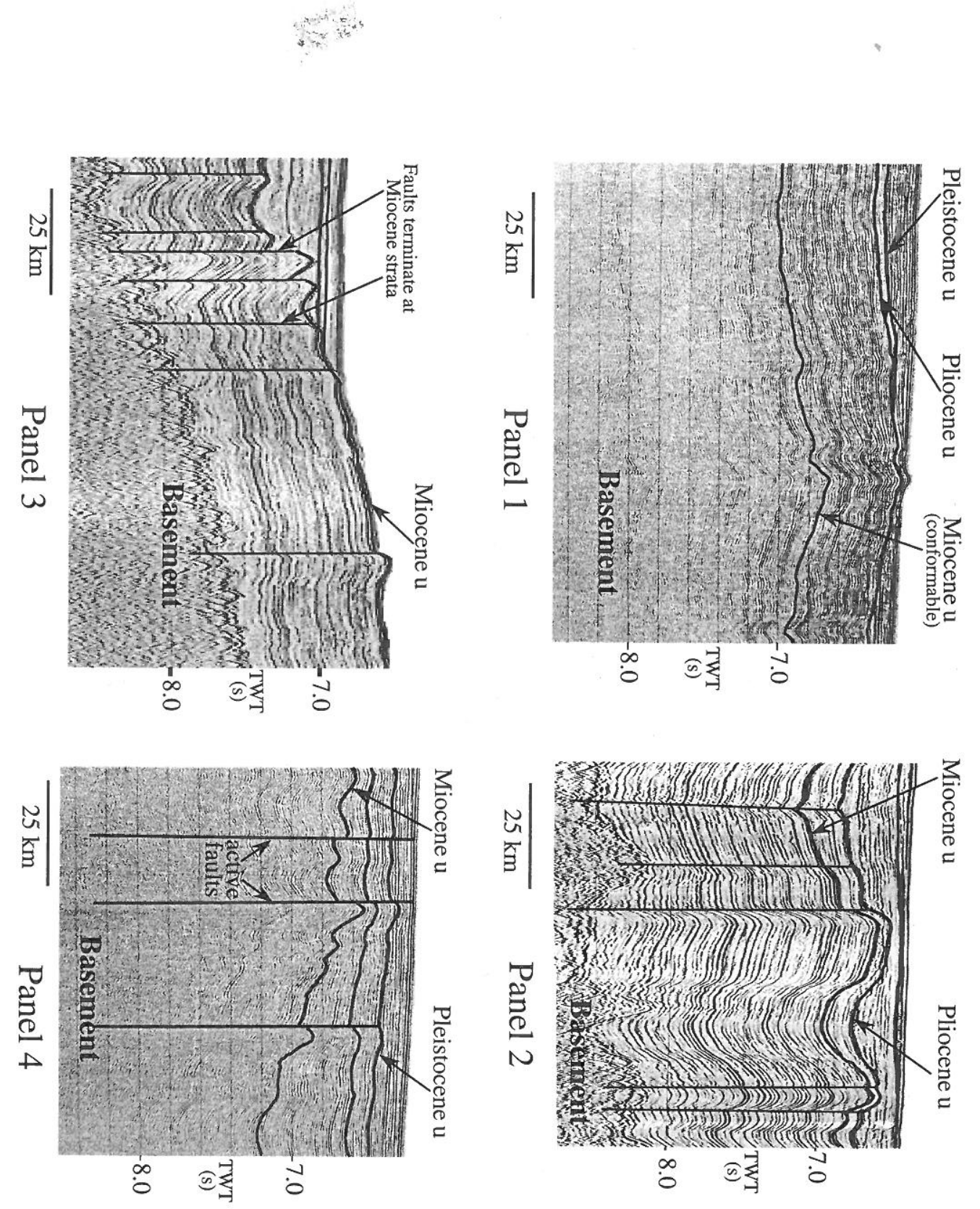


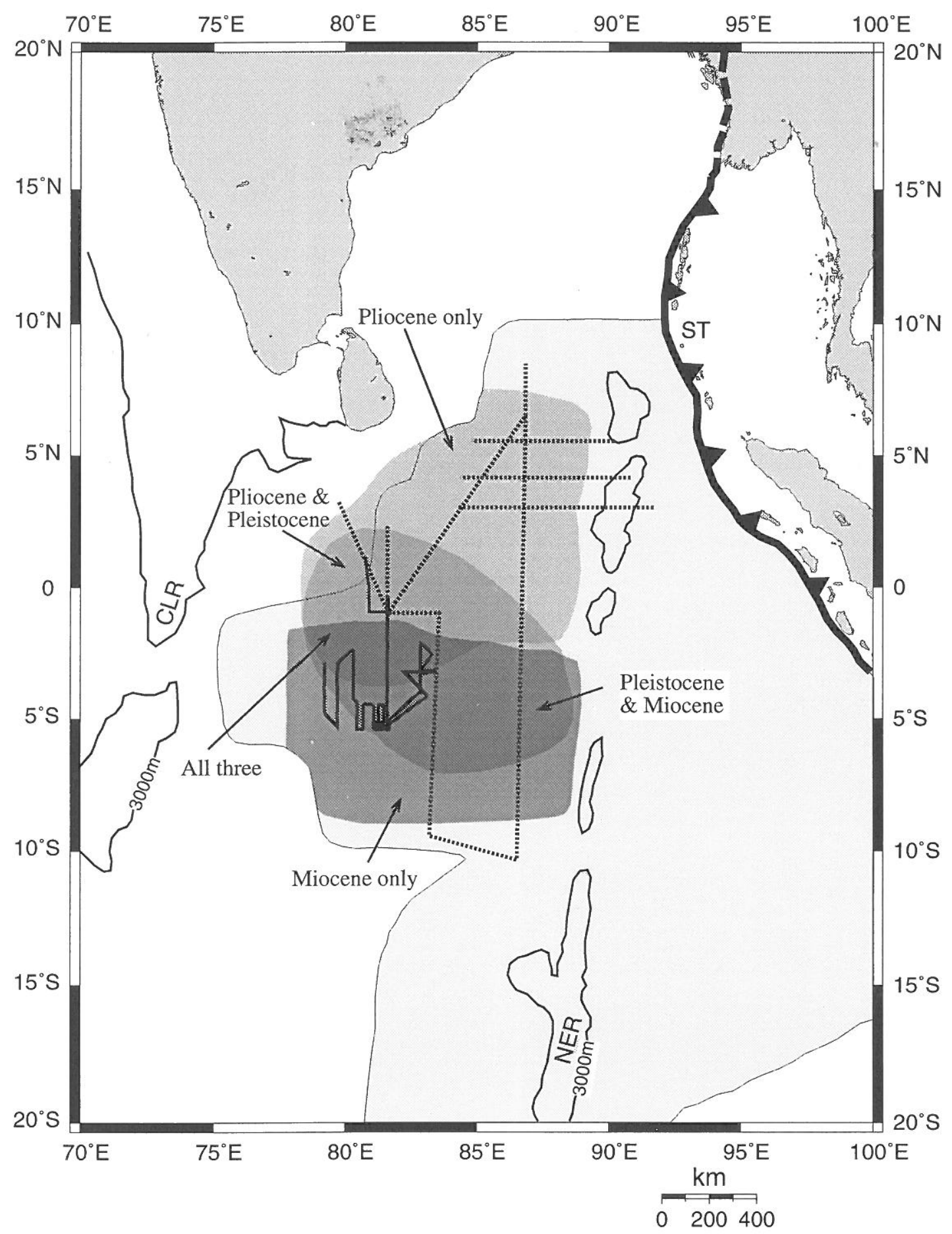

